\title{
The Teacher-Student Relationship in the Use of Social Network Sites for Educational Purposes: A Systematic Review
}

\author{
Laura Camas Garrido ${ }^{1} \odot$, Aída Valero Moya ${ }^{1} \odot$ and Mireia Vendrell Morancho ${ }^{2}(0)$ \\ ${ }^{1}$ Department of Educational Studies, Complutense University of Madrid, Spain \\ ${ }^{2}$ Department of Research and Psychology in Education, Complutense University of Madrid, Spain
}

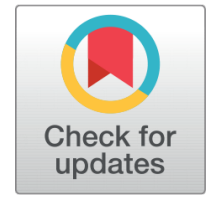

Received 2020-04-22

Revised 2020-05-11

Accepted 2020-10-26

Published 2021-01-15

Corresponding Author

Laura Camas Garrido,

laucamas@ucm.es

Universidad Complutense de Madrid-Facultad de Educación, Calle Rector Royo Villanova, s/n, 28040, Madrid, Spain.

DOI https://doi.org/10.7821/

naer.2021.1.591

Pages: 137-156

Distributed under

Creative Commons CC BY 4.0

Copyright: (C) The Author(s)

\section{OPEN ACCESS}

\section{ABSTRACT}

This paper aims at exploring the educational scholarly writing on the teacher-student relationship and performance within the use of Social Network Sites (SNSs) for educational purposes. To that end, a systematic review of 111 journal articles focused on young people, and found in ten relevant databases (ERIC, SCOPUS, WOS, JCR (SSCI), DOAJ, EBSCO, ISOC, REDIB, JSTOR, and PsycARTICLES), has been performed. The results show continuity in the roles of educators and students between physical and virtual spaces. This homogeneous conceptualisation is grounded on student-centred theories. Also, the existence of a theoretical confrontation between the figurative dichotomy of vertical (distance) and horizontal (closeness) teacher-student relationship is revealed and discussed. While most of the reviewed studies focused on requirements for technical training, the need for acquiring digital cultural knowledge is stressed. Finally, some of the educational implications of the ethical dimension of the teacher-student relationship in digital spaces are exposed.

Keywords SOCIAL NETWORK SITES, PEDAGOGICAL ISSUES, POST-SECONDARY EDUCATION, TEACHING STRATEGIES, 21ST CENTURY ABILITIES

\section{INTRODUCTION}

In the same way technologies did, Social Network Sites (SNSs) have grown into a worldwide phenomenon in which people connect, communicate, and socialise (Campbell et al., 2016). SNSs are considered online spaces where people open a public or private profile in order to interact with worldwide communities (Chugh \& Ruhi, 2018) linked by different interests and preferences (Abu-Shanab \& Al-Tarawneh, 2015; Arnold \& Paulus, 2010; Hatzipanagos \& John, 2017; Rodríguez, Ruiz-Palmero, \& Rivas, 2015; Vázquez-Martínez \& Cabero-Almenara, 2015) and transcending the time and space spheres of traditional social networks. Especially used but not limited to young people, SNSs have contributed to change the rules of traditional ways of communication. Thus, people are not only allowed to have 
direct access to knowledge and obtain up-to-date information and news, but they also play an active role by creating and sharing content on the web (prosumers) (Jover, del Rosario González Martín, \& Fuentes, 2015; Martínez, 2014; Nagel, Remillard, Aucoin, \& Takenishi, 2018). Since SNSs have occupied new channels for the interaction and communication, emerging educational challenges have surfaced (Alvarez-Flores \& Gómez, 2013; Kieslinger \& Ehms, 2010; Molinillo, Anaya-Sánchez, Aguilar-Illescas, \& Vallespín-Arán, 2018; Rodríguez et al., 2015).

The increasing interest in exploring the educational possibilities of using SNSs can be noticed when observing the academic literature of the last 10 years (Akçayır \& Akçayır, 2016; Fernández-Díaz, Rodríguez-Hoyos, \& Haya, 2017; Rodríguez-Hoyos, Salmón, \& Fernández-Díaz, 2015; Valero, Vendrell, \& Camas, 2018, 2020). Although most studies focus on the analysis of the educational use of SNSs as a medium, space, or tool that facilitates learning (Ling, 2014; Rama \& Chiecher, 2012; Sadowski, Pediaditis, \& Townsend, 2016; Túñez \& Sixto, 2012), there are few works that explore SNSs implications for the teacher-student relationship. Following the approach of some authors like Hershkovizt and Forkosh-Baruch (2017) and Jones, Gaffney-Rhys, and Jones (2011), the introduction of SNSs as educational settings has broken the hierarchical structures of traditional relationships. However, there is a lack of evidence that explores to what extent this phenomenon has supposed a real change in the traditional performance of educators and students, as well as in the way they interact and communicate in the community. Furthermore, while educational scenarios and performance are being rethought due to the COVID-19 crisis, digital tools have become an essential part of educational practises. In the light of this landscape, it is worth wondering what types of teacher-student relationships are fostered within the new digital settings, as well as what roles are emerging due to the use of SNSs as educational environments. Therefore, a thorough review of the academic literature that locates gaps and critically analyses the findings, implications, ambiguities, and challenges of the impact of SNSs on the teacher-student relationship is required.

\section{MATERIALS AND METHODS}

The overarching purpose of this work is to explore and synthesise what has been established on the educational use of SNSs and the teacher-student relationship in the scholarly literature. Accordingly, this work is aimed at creating an articulate theoretical systematic framework of the literature by means of a systematic review. That is, through structured and predefined processes selected in order to minimize bias and ensure that results are reliable and meaningful for readers (Higgins et al., 2019). In the light of this context and from a critical perspective, several questions arise around how the teacher-student relationship has been reported when using SNSs for educational purposes, under what theories the performance of educators and students is supported, and finally, what educational implications arise from these statements. Overall, this paper aims to:

- Select the most relevant academic papers on SNSs and teacher-student relationship in the academic literature. 
- Explore the impact that SNSs might have on the teacher-student relationship.

- Examine the performance of educators-students' when using SNSs for educational purposes.

- Articulate a theoretical framework of reference about the use of SNSs and their impact on the teacher-student relationship.

- Locate gaps that can indicate future lines of research.

In order to create a database with a comprehensive census of the literature for the educational use of SNSs, ten leading electronic databases were selected: ERIC, SCOPUS, WOS, JCR(SSCI), DOAJ, EBSCO, ISOC, REDIB, JSTOR, and PsycARTICLES. Next, with the purpose of identifying relevant literature in the selected databases, two detailed searches through search terms of interest were conducted at 4:09 p.m (UTC), April 18, 2019. The first search strategy was the following: (Allfields: "Social Network Sites" OR "Social Networking Sites" OR "Redes Sociales") AND (Abstract: (Education) OR (Teaching) OR (Learning) OR (Educación) OR (Enseñanza) OR (Aprendizaje)). Subsequently, with the object of finding articles better suited to the subject of study, a search strategy that used more specific terms was designed. This was the following: (Abstract: ("Social Network Sites" OR "Social Networking" OR "Social Networks")) AND (Abstract: ("Teacher-student Relationship" OR "Student-teacher Relationship" OR "Student Performance" OR “Teacher Performance")). Aside from the search terms, the strategy encompassed five inclusion criteria: journal articles (as document type); 2006-2019 (as timespan); Spanish and English (as publication language); peer-reviewed; and full-text academic articles. In relation to geographical characteristics, no specific sample features were established. Similarly, no sociodemographic restrictions were applied. Upon completion of the search process, 4,437 academic works were identified as potentially relevant for this study (see Figure 1).

Afterwards, article titles and abstracts were scanned for relevance by one reviewer according to a comprehensive set of 6 inclusion and exclusion criteria (see Table 1). Once the scanner was completed, a second reviewer checked the selection and discrepancies were resolved through a consensus discussion with a third reviewer. This search yielded a total of 474 articles. Afterwards, a total of 69 duplicated studies were removed. At this point, the content of the 405 articles was skimmed by the three reviewers. This process ended with the removal of 249 articles for failing to meet eligibility criteria and incorporating 24 through a snowball technique, leaving 111 articles relevant to the subject of this study. The Snowball technique consists of identifying relevant references cited in the selected papers in order to increase the number of sources revised (Wnuk \& Garrepalli, 2018; Wohlin, 2014). Finally, the 111 selected articles were subsequently read, further analysed through a standardised data extraction, and categorised into 3 main categories: a) teacher-student interaction and communication, b) teachers' and students' performance and c) teacher-student relationship. To calculate the reliability of the coding, an external observer carried out the analysis of $20 \%$ of the data $(n=22)$. To assess reliability, the Kappa de Cohen coefficient was calculated with the aim of measuring the degree of agreement between the coding made by the researchers and the external observer. The kappa coefficient of Cohen shows a concordance force $(k=0.71)$ that we could categorize as "good" following the works of Fleiss 


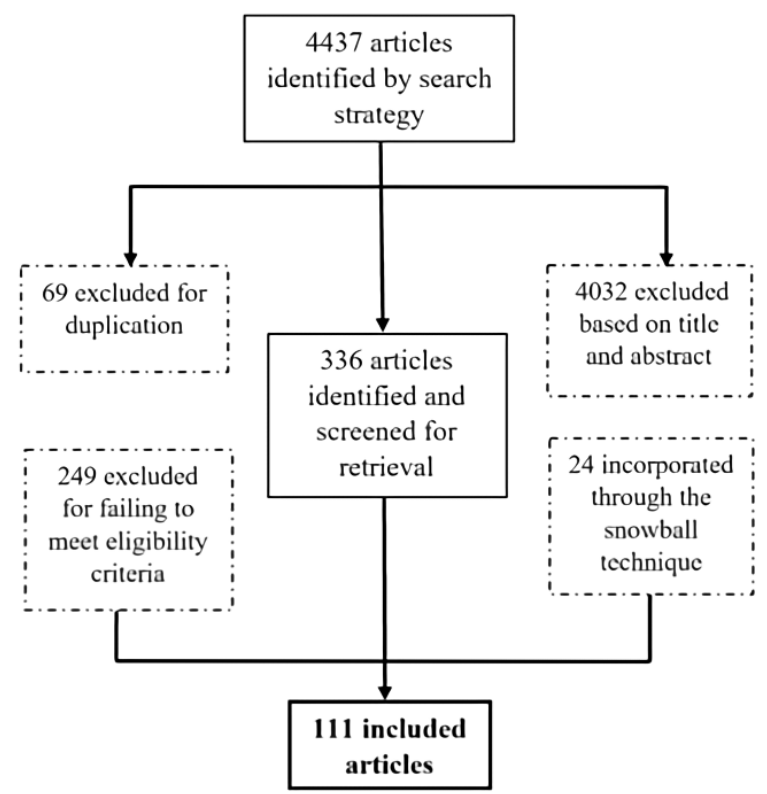

Figure 1 Flow diagram of identification of eligible studies

(1981) and Altman (1991) $(0.61<\mathrm{k}<0.75$ and $0.61<\mathrm{k}<0.80$, respectively). Discrepancies were resolved by discussion.

Table 1 Inclusion and exclusion criteria

\section{Criterion}

(1) Content

(2) Language

(3) Reviewed procedure

(4) Full-text

(5) Population

(6) Level of Education

\section{Included}

(1.1) Aimed at the use of SNSs within formal educational contexts (1.2) Bonded with teacher-student relationship

(2.1) Spanish and English

(3.1) Peer-reviewed academic journal articles

(4.1) Full-text available

(5.1) Teenagers or young people

(6.1) Secondary and tertiary education

\section{Excluded}

(1.3) Related to non-formal education(1.4) Not bonded with teacher-student relationship

(2.2) Other languages

(3.2) Not evaluated by a peer-reviewed procedure

(4.2) Non full-text online available

(5.2) That do not refer to teenagers or young people

(6.2) Other levels of education

\section{RESULTS}

As several studies have highlighted, one of the major implications of the countless possibilities for socialising through SNSs concerns the relationship between teachers and students (Bosch, 2009; Cheung \& Vogel, 2011; Madge, Meek, Wellens, \& Hooley, 2009; Selwyn, 2009) and its quality in favour of academic performance (Birch \& Ladd, 1998; Callaghan \& Bower, 2012; Ha \& Shin, 2014; Hamre \& Pianta, 2001; Hershkovitz \& Baruch, 2013; Hershkovizt \& Forkosh-Baruch, 2017; Hutchens \& Hayes, 2014; Mazer, Murphy, \& Simonds, 2007; Sabol \& Pianta, 2012). With regard to these statements and considering that virtual spaces are encouraging a new culture of reasoning and functioning (Liu, Maes, \& Davenport, 2006; Padilla, 2012), it is worth exploring their educational implications. 


\subsection{Teacher-Student Interaction and Communication}

There is a general agreement in the literature on the statement that SNSs are intended to promote interpersonal connections and interactions among the community (Abu-Shanab \& Al-Tarawneh, 2015; Chiroma et al., 2017; Chugh \& Ruhi, 2018; Colás-Bravo, CondeJiménez, \& Martín-Gutiérrez, 2015; Erjavec, 2013; Gafni \& Deri, 2012; Gomez et al., 2013; Heo \& Lee, 2013; Hershkovizt \& Forkosh-Baruch, 2017; Hollyhead, Edwards, \& Holt, 2012; Lang, 2012; Seifert, 2016). Considering the teacher-student relationship, the interactions produced within SNSs are usually framed under a constructivism approach. Following the assumptions of Vygotsky's Zone of Proximal Development (ZPD), justified in some works such as in the one of Fernández-Díaz et al. (2017) or Yakin and Tinmaz (2015), the nature of SNSs promotes interaction, reflection, exchange of information, and collaborative knowledge construction among stakeholders. In this context, these characteristics are likely to generate spaces for the collaborative construction of learning (Al-Rahmi \& Zeki, 2017; Asterhan \& Bouton, 2017; Cabero \& Marín, 2014; Charles, 2012; Chugh \& Ruhi, 2018; Dewick \& Miozzo, 2004; Esquivel \& Rojas, 2014; Jang, 2015; Jiang, Tang, Peng, \& Liu, 2018; Junco, Elavsky, \& Heiberger, 2013; Keng \& Ching, 2015; Liccardi et al., 2007; Ling, 2014; López-Bonilla \& López-Bonilla, 2013; Manca \& Ranieri, 2017; Maroulis \& Gomez, 2008; Mccarthy, 2010; Morón, López, \& Cobos, 2017; Phungsuk, Viriyavejakul, \& Ratanaolarn, 2017; Ricoy \& Feliz, 2016; R. B. Wang \& Du, 2014). In particular, research by Al-Rahmi and Zeki (2017) showed that collaborative learning mediated by SNSs has a positive influence on student performance. Aiming to create collaborative environments, Phungsuk et al. (2017) argued the need to create a "virtual learning environment" in which the SNSs are the communication system that allows students to have collaborative experiences. Authors such as Jiang et al. (2018) have pointed out that the type of collaborative relationships created while using SNSs for educational purposes are more equitable and egalitarian as they offer the same opportunities for participation to all students.

As interactions are defined in terms of active participation and multidirectionality, SNSs provide a boost, not only between teachers and students but also among peers, families, authorities, or other socialisation agents (Badri, Alnuaimi, Rashedi, Yang, \& Temsah, 2017; Chiroma et al., 2017; Hamid, Waycott, Kurnia, \& Chang, 2015; Rama \& Chiecher, 2012; Thalluri \& Penman, 2015; Wu, 2014). In this regard, several studies have found a positive relationship between peers' interaction within SNSs and academic achievement (de Laat, Lally, Lipponen, \& Simons, 2007; Maroulis \& Gomez, 2008; Martínez, Dimitriadis, Rubia, Gómez, \& de la Fuente, 2003; Putnik et al., 2016; Romero, López, Luna, \& Ventura, 2013; Russo \& Koesten, 2005; Vercellone-Smith, Jablokow, \& Friedel, 2012), measuring them in terms of support and social influence in most of these works.

At the same time, there are some studies that have framed the scholar interactions in terms of communication as a more complex and wider process than mere interactivity (Alvarez-Flores \& Gómez, 2013; Hershkovizt \& Forkosh-Baruch, 2017; Leite, Hoji, \& Junior, 2018; Seifert, 2016; Túñez \& Sixto, 2012). The review carried out by Froment, García, and Bohórquez (2017) on the impact of SNSs on teacher-student communication is remarkable. Their work reviews numerous papers that show the positive correlation 
between the communicative use of SNSs and motivation and empowerment among students, creation of a positive learning environment and satisfaction among students. Special emphasis was placed on Facebook groups as they promote satisfaction and conflict resolution (Hershkovizt \& Forkosh-Baruch, 2017). Following this conceptualisation, the communicative potential of SNSs lies in the numerous opportunities for teachers and students to: a) be engaged in attractive discussions and activities, normally through forums, informal working, or focalised group sessions (López, Flores, \& Espinoza, 2015; Romero et al., 2013; Vercellone-Smith et al., 2012), b) being in touch in and outside the classroom (Túñez \& Sixto, 2012), c) sharing thoughts and feelings about academic performance (Norman, Nordin, Din, Ally, \& Dogan, 2015), d) providing an individualised rapport (Froment et al., 2017), or e) solving specific aspects of learning tasks (Chugh \& Ruhi, 2018; Rama \& Chiecher, 2012; Vázquez-Martínez \& Cabero-Almenara, 2015).

\subsection{Teacher-Student Performance}

The inclusion of SNSs in educational settings has suggested possible and multiple understandings about what learning means as well as variations in the performance of teachers and students (Greenhow, Gleason, \& Li, 2014; Hershkovizt \& Forkosh-Baruch, 2017; Leite et al., 2018; Putnik et al., 2016). At this point, it is important to remark that this inclusion of the SNSs does not constitute the mere expansion of their use for students' entertainment; it might also involve a significant change in the traditional roles of educators and learners. Regarding the role of educators, teachers play an essential role in the effective implementation of SNSs as educational settings (Hutchens \& Hayes, 2014; Vázquez-Martínez \& Cabero-Almenara, 2015). As a result of the review of the literature, two main roles referring to educators' performance have been detected.

Firstly, the need for teachers to be technologically competent seems to be highly relevant to students' academic performance (Seifert, 2016). Following this assumption, Martínez (2014) expresses that educators not only have to be trained in the attitudes towards and implications and possibilities of SNSs, but also in some of their technology skill set, such as creating content, analysing information, evaluating procedures and tools, or disseminating data widely. Considering that students are digital natives, teachers are required to become 'as savvy as their students' (Blair \& Serafini, 2014, p. 28), which means that both parties should develop similar digital competencies (Rama \& Chiecher, 2012). Therefore, educators have to be technologically competent in order to integrate SNSs into their teaching practice effectively.

Secondly, several authors lay stress not only on the demand of teachers to acquire digital competencies but also on acting as mediators in spaces of participation. According to Lackovic, Kerry, Lowe, and Lowe (2017), Chugh and Ruhi (2018), and Ling (2014), the role of teachers is conceptualised in the light of the student-centered methodologies, where educators act as facilitators of learning into participatory and collaborative environments (Charles, 2012; Seifert, 2016).

The characteristics of this type of educator's role are concreted in an empirical study conducted by Hernández and Medina (2015): 1) tutor (27.5\%), 2) provider of students' feed- 
back (25.9\%), and 3) facilitator and learning' invigorating (21.4\%). Likewise, some other functions such as planner, organiser, or moderator were also considered in the study. At the same time, a considerable number of authors have specified some of the responsibilities with regard to the teacher functions: a) being available to help students to be integrated into the digital culture; b) establishing significant links between physical and virtual spaces; c) defining the criteria and rules of participation in the educational scenarios; d) selecting the most appropriate SNS; e) producing and organising pedagogical content, materials and activities; h) promoting dialogue and interaction among the learning community; f) participating and collaborating with their students as an equal member; g) fostering students' motivation; h) offering different sources of information; and i) evaluating the teaching and learning process (Ling, 2014; Palacios, 2012; Pérez, Tur, Negre, \& Lizana, 2017; Phungsuk et al., 2017; Rama \& Chiecher, 2012; Seifert, 2016; Túñez \& Sixto, 2012; Vázquez-Martínez \& Cabero-Almenara, 2015).

Moreover, the recent studies of Camas, Valero, and Vendrell (2018) and Nagle (2018) relate the participatory role of educators to the construction of a democratic culture based on educating in critical and digital literacy. Following this line of thought, according to Morón et al. (2017), the SNSs are suitable environments for the promotion of global citizenship and "democratic, critical, sustainable, supportive and participatory" values (p.13). Along with the abovementioned responsibilities, these authors emphasise the dialogical possibilities of SNSs to promote discussions about social topics where democratic values are likely to be acquired. Some of the educational strategies that might be useful for achieving this goal are: a) to suggest topics about unfair and exclusive situations, b) to conceive participatory technologies as a choice, and c) to prevent and respond to the pitfalls of SNSs by offering supportive tools. Following these implications, teachers might act as a guide to the teaching and learning process (Cao \& Hong, 2011), whereas the active role of the student is boosted under the principles of a democratic society.

In relation to the student's performance, the role of students as active agents in their own learning process has been remarked by the majority of the scholarly works analysed (Gonzalez \& Delgado, 2016; Keats \& Schmidt, 2007; Norman et al., 2015; Phungsuk et al., 2017; Rama \& Chiecher, 2012; Túñez \& Sixto, 2012; Vázquez-Martínez \& Cabero-Almenara, 2015). More precisely, the possibilities of interaction, collaboration, and participation of SNSs place the student at the centre of the teaching practices, letting them become the real protagonist of the educational process (Chen \& Fang, 2014; Chiroma et al., 2017; Seifert, 2016; Túñez \& Sixto, 2012). This autonomy is highlighted so that they might have the responsibility of 'what and how they want to learn', in terms of Phungsuk, Viriyavejakul, \& Ratanaolarn (2017, p. 303).

Following a 'self-directed learning model' (Gonzalez \& Delgado, 2016; Seifert, 2016) students have to manage their own time efficiently, be self-motivated, solve their problems, or make their own decisions. The traditional reactive attitudes and actions become proactive, having a clear and active implication, and commitment to the teaching and learning process (Rama \& Chiecher, 2012; Túñez \& Sixto, 2012; Vázquez-Martínez \& Cabero-Almenara, 2015). Likewise, Norman et al. (2015) found diverse student roles in mobile media learning 
that affect the proper implementation of SNSs (ordered from lower to higher participation): a) lurker; b) gradually mastering member or passive member; c) recognised member, and d) coach. As shown, they found the presence of passive members when the entire teaching and learning process was accomplished by using mobile devices. This may suggest some limitationswhen leading students to develop their total activity exclusively across digital spaces. On the one hand, some limitations are related to the promotion of learners' passive attitudes towards participation, lower commitment of teachers when students use digital environments, or the lack of physical teacher-student' interaction (Alvarez-Flores \& Gómez, 2013; Ling, 2014; Martínez, 2014; Norman et al., 2015; Rama \& Chiecher, 2012; Túñez \& Sixto, 2012). On the other hand, other studies have found a relationship between the frequency in the use of SNSs and academic achievement, so that the latter increases when the student displays a moderate use of SNSs (Abu-Shanab \& Al-Tarawneh, 2015; AlYafi, El-Masri, \& Tsai, 2018; Paul, Baker, \& Cochran, 2012) and avoids passive or addictive uses (Arquero \& Romero-Frías, 2013; Buck, 2012; Gafni \& Deri, 2012; Huang, 2018).

As $21^{s t}$ century learners, some findings in the literature remind us that students not only have to be literate in a variety of digital technologies of communication but also in the critical use of SNSs (Ling, 2014; Nagle, 2018; Vázquez-Martínez \& Cabero-Almenara, 2015). On the one hand, despite the fact that they are natural users of digital environments (Hershkovizt \& Forkosh-Baruch, 2017), they also need to develop digital competencies and skills for their proper instrumental usage (Rama \& Chiecher, 2012). Likewise, other transversal skills such as teamwork, leadership, self-confidence, or autonomy in decision-making, are expected to be developed (Leite et al., 2018). Moreover, students need to be aware of the ethical implications of using SNSs responsibly as well as acquiring democratic values. SNSs constitute spaces full of civic content and, therefore, have the potential for the development of students' democratic engagement (Camas et al., 2018).

\subsection{The Distance and Closeness of the Teacher-Student Relationship}

Among other factors, one of the most relevant implications of the educational possibilities of SNSs concerns the limits in the construction of the teacher-student relationship (Daly, Moolenaar, Bolivar, \& Burke, 2010; Froment et al., 2017; Seifert, 2016). Firstly, the establishment of closer relationships between educators and students as well as the improvement of the teaching climate has been remarked by several authors (Asterhan \& Rosenberg, 2015; Kio, 2015; Ling, 2014; Maroulis \& Gomez, 2008; Mazer et al., 2007; Roblyer, McDaniel, Webb, Herman, \& Witty, 2010; Seifert, 2016; Thalluri \& Penman, 2015; Túñez \& Sixto, 2012). Along with Cotton (1996), Maroulis and Gomez (2008), and Raywid (1997), the extended and meticulous work of Froment et al. (2017) evidenced that SNSs favour a more individualised follow-up, which facilitates a deeper personal knowledge of students and teachers. Likewise, the idea that communication and effective relationships are promoted in a positive way within these environments is highly sustained (Abella \& Delgado, 2015; Albayrak \& Yildirim, 2015; Amador \& Amador, 2014; Aydin, 2012; BowersCampbell, 2008; Conole \& Culver, 2010; Hernández \& Medina, 2015; Irwin, Ball, Desbrow, \& Leveritt, 2012; Lee, Lee, \& Kim, 2015; Ormart \& Navés, 2014; Rezende, van Kruistum, \& 
van Oers, 2016; Rienties \& Kinchin, 2014; Roblyer et al., 2010; Saifudin, Yacob, \& Saad, 2016; Sobaih, Moustafa, Ghandforoush, \& Khan, 2016; J. Wang, 2013; Wodzicki, Schwämmlein, \& Moskaliuk, 2012). The study by Saifudin et al. (2016) showed that the use of Facebook groups for educational purposes strengthened the links and relationship between students and teachers. This approach was particularly relevant to students in the early and late stages of undergraduate studies. In this sense, Rezende et al. (2016) have reviewed two trends about using Facebook groups as a "Class Agenda" and as a forum in order to increase knowledge about "interdisciplinary themes" (p. 238). These authors also showed that the use of SNSs increased the relationship and the closer and more fluid interaction not only in the virtual class but also in the face-to-face context.

On the contrary, there are some studies that express the negative consequences that exceeding the closeness or keeping an excessive distance in the teacher-student relationship might have. First of all, teachers and students becoming friends might lead to: a) lack of educators' authority (Chugh \& Ruhi, 2018; Cole, Hibbert, \& Kehoe, 2013; Gomez et al., 2013), b) sense of favouritism felt by some student, c) excess of personal information uploaded on the stakeholders' profiles, d) damage use of information disclosure, complacency, or e) loss of motivation and the deterioration of academic performance (Evans, 2014; Froment et al., 2017; Jones et al., 2011). Subsequently, the promotion of authoritative and non-dialogical interactions (Charles, 2012; Kio, 2015) and the risk of replacing the faceto-face interaction and communication among stakeholders (Badri et al., 2017; Ling, 2014; Martínez, 2014; Rama \& Chiecher, 2012; Sadowski et al., 2016; Túñez \& Sixto, 2012) have been remarked when their relationship tends to distance. For that matter, the statement that digital interactions should never replace the physical spaces and times for communicating has been highlighted in the aforementioned works. Finally, and in an attempt to find the proper balance, there are some studies that support the suitability of negotiating the limits of this relationship (Charles, 2012; Hershkovizt \& Forkosh-Baruch, 2017; Kio, 2015).

\section{DISCUSSION AND CONCLUSIONS}

Along with other technological paths, the phenomenon of SNSs in education has inevitably led to new educational challenges. As a result of this systematic review, the principal implications of the incorporation of SNSs for educational purposes concerning the teacherstudent relationship and their performance have been exposed.

First of all, the vast majority of the studies sustain that the use of SNSs in educational settings contributes to breaking the traditional hierarchical relationships and, thus, the promotion of horizontal ones (see 3.2 section). In fact, one aspect that would be interesting to consider is whether the breakdown of this traditional hierarchy occurs in the same way in the use of vertical or horizontal SNSs. However, the controversies concerning the effects of SNSs on the teacher-student relationship are still under debate. On the one hand, the positive effects of this supposed change, especially on students' motivation, engagement, and participation, have been justified in the literature reviewed. Besides, it might be ambiguous and complex to find where the limits are as well as achieving the appropriate balance with 
regard to the distance or closeness of this relationship. Should educators have to become friends or 'followers' or keep their distance from their students? Is the teacher-student relationship endangered when exceeding the limits of professionalism due to an over-closeness? As it has been argued, the limits are highly dependent on different variations among institutions, cultures, policies, regions, or countries. For instance, while some countries, such as Ireland, regulate the teacher-student communication via SNSs by its educational legislation, this communication, unless in exceptional circumstances, is considered unacceptable in countries, such as Australia (Hershkovizt \& Forkosh-Baruch, 2017). Nevertheless, there seems to be an agreement when establishing the negative effects of an inappropriate or irresponsible use of SNSs on the teacher-student relationship (see 4.3 section). This evidence leads us to the classic debate about the reflection on whether the educator should be an authority figure (which does not mean authoritative, see Martínez, Esteban, Jover, and Payá (2018) or acting as a leader of the educational process. In fact, most of the studies have conceptualised this issue under a dichotomous logic through which distance and closeness are confronted. This argumentative logic places on a single analytical level the terms of distance and verticality as well as closeness and horizontality. However, is it possible to find a matching position in which both options come together? In the attempt to overcome this reductionist view, the way to conserve the authority status (avoiding authoritative approaches), while also providing closeness is still being explored. Consequently, the teacher-student relationship should tend to a horizontal closeness, similar to friendship, but maintaining the vertical distance when considering ethical and responsible boundaries. And this should be independent of the nature of the SNS that is intended to be used for educational purposes. To follow this perspective would result in a relationship defined by horizontality under the premise of a different symmetry (authority) in the roles of students and teachers. Therefore, the tension between distance and closeness would be relieved.

Secondly, two educational implications have been found in relation to the way of using SNSs for educational purposes concerning teacher-student performance. In the first place, there seems to be a continuity in both physical and virtual spaces. Assuming this argument, the student-teacher relationship is grounded in student-centred pedagogies where educators act as mediators with the knowledge. At the same time, a clear commitment to the limelight of students in the learning process is highlighted. Therefore, when the teacher-student performance in the educational use of SNSs is analysed, the search for coherence from the theoretical frameworks of active pedagogies are observed. This could imply that this use does not seem to involve a reconfiguration of the student-educator's roles but rather a new expression of the same theoretical purpose. Afterwards, although studies usually take it for granted, the mere application of SNSs into educational settings does not necessarily guarantee an education based on the theory of active pedagogies. Moreover, although the scenario and educational tools in virtual settings have been metamorphosed, the teacher-student relationship are routed in the student-centred approach. Despite finding many similarities in the type of relationship within physical and virtual spaces, the introduction of technology has led to the literacy of teachers with tools and strategies of the virtual environment. For this reason, some authors have argued that the introduction of SNSs in the classroom might 
be considered an educational innovation. However, would this consideration be sufficient to affirm that SNSs modernise the teacher-student relationship? These controversies have led to the debate about whether this implementation constitutes an innovative element. More studies on these issues are necessary.

Thirdly, the controversies around the role of teachers increase when students, as native users of SNSs and digital spaces, are able to manage them even better than educators. Although the teacher needs to be literate in technical knowledge about the use, risks, and good practices of the SNSs, there is a question that no article seems to highlight. Beyond the digital and technical literacy, teachers should also be trained in the knowledge of the digital culture shared by their students. This means that young people have cultural codes that guide their behaviours and the way they participate, also in the network. Therefore, teachers should make efforts to approach, know, and understand those cultural forms. Its importance lies in the need to ensure continuity in the culture of participation in digital scenarios within the ethical parameters. If the teacher refuses to become literate in that subculture, there is a risk of creating discontinuities and, hence, their attempt to educate could be frustrated. This situation might expand the conception of the learner to these agents and make educators prioritise the ethical use of SNSs over their technical utilization. In fact, as some authors have pointed out (Camas et al., 2018), the power of SNSs in digital times lies in the construction of a democratic culture and active citizenship. Thus, the need for boosting proper use of SNSs in ethical terms should be one of the main purposes that educators should follow, especially considering the risks of an inappropriate performance (Badri et al., 2017; Forbes, 2017; Paul et al., 2012; Renes-Arellano, Caldeiro-Pedreira, del Mar Rodríguez-Rosell, \& Aguaded, 2018). In order to contribute to this issue, the need for developing a system of indicators which considers SNSs' principal risks, boundaries, recommendations, and challenges emerges.

Finally, another debate arises from the potential controversies that stopping worrying about the students' activity within digital spaces could lead to. This statement might be justified with an erroneous perception of the idea that the student is sufficiently autonomous to assume the full responsibility of their own learning process and to navigate through these environments without any supervision. Some negative effects of providing students with unlimited independence have been found (see 3.2 section). All in all, to be an educator within digital spaces does not mean disregarding the responsibility of creating continuity among different contexts, but also implies ensuring students' welfare.

Once the systematic review has been achieved, it is worth mentioning some limitations. First of all, the present study has only considered journal articles focused on the educational implications of the use of SNSs on the teacher-student relationship. Meanwhile, any books, chapters, or conferences have not been taken into consideration. Secondly, the fact that we only selected and analysed those articles written in English and Spanish constitutes another limitation for similar reasons. Thirdly, criteria related to the inclusion of openaccess articles might ignore potential findings of the topic. Thus, the possibility to include other articles with different access policies will be considered. Another limitation is led by the fact that most of the articles make no difference between blended and face-to-face 
learning. In this light, these ways of learning might probably have different implications on the teacher-student relationship. Consequently, they need to be considered separately for future research. Finally, future lines of research could be focused on unexplored statements, such as which digital spaces or educational strategies could facilitate the relationship between educators and students and, if so, which ones are more likely to have a positive impact on students' academic performance.

To sum up, although the use of SNSs for educational purposes has proliferated new pedagogical realities, it seems to be a theoretical continuity in conceptualisation of the teacherstudent relationship in both virtual and face-to-face classes. While there would not be a significant change in the theorisation of the teacher-student relationship, this argument does not nullify the possibility that SNSs are spaces laden with educational challenges in the teacher-student relationship.

\section{REFERENCES}

Abella, V., \& Delgado, V. (2015). Aprender a usar Twitter y usar Twitter para aprender. Profesorado. Revista de Currículum y formación de profesorado, 19(1), 364-378. Retrieved from http:// www.ugr.es/ recfpro/rev191COL5.pdf

Abu-Shanab, E., \& Al-Tarawneh, H. (2015). The Influence of Social Networks on High School Students' Performance. International Journal of Web-Based Learning and Teaching Technologies, 10(2), 49-59. https://doi.org/10.4018/ijwltt.2015040104

Akçayır, G., \& Akçayır, M. (2016). Research trends in social network sites' educational use: a review of publications in all SSCI journals to 2015. Review of Education, 4(3), 293-319. https:// doi.org/10.1002/rev3.3075

Albayrak, D., \& Yildirim, Z. (2015). Using Social Networking Sites for Teaching and Learning: Students' Involvement in and Acceptance of Facebook as a Course Management System. Journal of Educational Computing Research, 52(2), 155-179. http://doi.org/10.1177/ 0735633115571299

Al-Rahmi, W. M., \& Zeki, A. M. (2017). A model of using social media for collaborative learning to enhance learners' performance on learning. Journal of King Saud University - Computer and Information Sciences, 29(4), 526-535. https://doi.org/10.1016/j.jksuci.2016.09.002

Altman, D. G. (1991). Practical statistics for medical research. Chapman and Hall.

Alvarez-Flores, E. P., \& Gómez, P. N. (2013). Uso de redes sociales como elemento de interacción y construcción de contenidos en el aula: cultura participativa a través de Facebook. Historia y Comunicación Social, 18(0), 53-62. https://doi.org/10.5209/rev_hics.2013.v18.44225

Al-Yafi, K., El-Masri, M., \& Tsai, R. (2018). The effects of using social network sites on academic performance: the case of Qatar. Journal of Enterprise Information Management, 31(3), 446462. https://doi.org/10.1108/jeim-08-2017-0118

Amador, P., \& Amador, J. (2014). Academic advising via Facebook: Examining student help seeking. The Internet and Higher Education, 21, 9-16. https://doi.org/10.1016/j.iheduc.2013.10.003

Arnold, N., \& Paulus, T. (2010). Using a social networking site for experiential learning: Appropriating, lurking, modeling and community building. The Internet and Higher Education, 13(4), 188-196. https://doi.org/10.1016/j.iheduc.2010.04.002

Arquero, J. L., \& Romero-Frías, E. (2013). Using social network sites in Higher Education: an experience in business studies. Innovations in Education and Teaching International, 50(3), 238-249. https://doi.org/10.1080/14703297.2012.760772 
Asterhan, C. S., \& Bouton, E. (2017). Teenage peer-to-peer knowledge sharing through social network sites in secondary schools. Computers \& Education, 110, 16-34. Retrieved from https://dx.doi.org/10.1016/j.compedu.2017.03.007 10.1016/j.compedu.2017.03.007

Asterhan, C. S., \& Rosenberg, H. (2015). The promise, reality and dilemmas of secondary school teacher-student interactions in Facebook: The teacher perspective. Computers \& Education, 85, 134-148. https://doi.org/10.1016/j.compedu.2015.02.003

Aydin, S. (2012). A review of research on Facebook as an educational environment. Educational Technology research and development, 60(6), 1093-1106. http://doi.org/10.1007/s11423-012 $-9260-7$

Badri, M., Alnuaimi, A., Rashedi, A. A., Yang, G., \& Temsah, K. (2017). School children's use of digital devices, social media and parental knowledge and involvement - the case of Abu Dhabi. Education and Information Technologies, 22(5), 2645-2664. http://doi.org/10.1007/ s10639-016-9557-y

Birch, S. H., \& Ladd, G. W. (1998). Children's interpersonal behaviors and the teacher-child relationship. Developmental Psychology, 34(5), 934-946. https://doi.org/10.1037/0012-1649.34.5 .934

Blair, R., \& Serafini, T. M. (2014). Integration of education: Using social media networks to engage students. Systemics. Cybernetics, and Informatics, 6(12), 28-31. https://doi.org/10.7771/1481 $-4374.2247$

Bosch, T. E. (2009). Using online social networking for teaching and learning: Facebook use at the University of Cape Town. Communicatio, 35(2), 185-200. https://doi.org/10.1080/ 02500160903250648

Bowers-Campbell, J. (2008). Cyber "Pokes": Motivational Antidote for Developmental College Readers. Journal of College Reading and Learning, 39(1), 74-87. https://doi.org/10.1080/ 10790195.2008.10850313

Buck, A. (2012). Examining digital literacy practices on social network sites. Research in the Teaching of English, 9-38.

Cabero, J., \& Marín, V. (2014). Posibilidades educativas de las redes sociales y el trabajo en grupo. Percepciones de los alumnos universitarios. Comunicar, 21(42), 165-173.

Callaghan, N., \& Bower, M. (2012). Learning through social networking sites - the critical role of the teacher. Educational Media International, 49(1), 1-17. https://doi.org/10.1080/09523987 .2012.662621

Camas, L., Valero, A., \& Vendrell, M. (2018). Hackeando memes: cultura democrática, redes sociales y educación. Espiral. Cuadernos del profesorado, 11(23), 120-129.

Campbell, S., Chong, S., Ewen, V., Toombs, E., Tzalazidis, R., \& Maranzan, K. A. (2016). Social media policy for graduate students: Challenges and opportunities for professional psychology training programs. Canadian Psychology/Psychologie canadienne, 57(3), 202-210. https:// doi.org/10.1037/cap0000053

Cao, Y., \& Hong, P. (2011). Antecedents and consequences of social media utilization in college teaching: A proposed model with mixed-methods investigation. On the Horizon, 19(4), 297306. http://doi.org/10.1108/10748121111179420

Charles, A. S. (2012). Cell phones: Rule-setting, rule-breaking, and relationships in classrooms. American Secondary Education, 40(3), 4-16.

Chen, S. Y., \& Fang, S. P. (2014). Taiwanese college students' reading practices and profiles in both print-and internet-based formats. Reading Improvement, 51(3), 319-331.

Cheung, R., \& Vogel, D. (2011). Can Facebook Enhance the Communications between Teachers and Students? The International Journal of Learning: Annual Review, 17(11), 385-398. https:// doi.org/10.18848/1447-9494/cgp/v17i11/47356 
Chiroma, H., Shuib, N. L. M., Abubakar, A. I., Zeki, A. M., Gital, A. Y., Herawan, T., \& Abawajy, J. H. (2017). Advances in Teaching and Learning on Facebook in Higher Institutions. IEEE Access, 5, 480-500. https://doi.org/10.1109/access.2016.2643682

Chugh, R., \& Ruhi, U. (2018). Social media in higher education: A literature review of Facebook. Education and Information Technologies, 23(2), 605-616. https://doi.org/10.1007/s10639-017 $-9621-2$

Colás-Bravo, P., Conde-Jiménez, J., \& Martín-Gutiérrez, A. (2015). Las redes sociales en la enseñanza universitaria: Aprovechamiento didáctico del capital social e intelectual. Revista interuniversitaria de formación del profesorado, 83, 105-116. Retrieved from https://www .redalyc.org/pdf/274/27443659008.pdf

Cole, M. L., Hibbert, D. B., \& Kehoe, E. J. (2013). Students' Perceptions of Using Twitter To Interact with the Instructor during Lectures for a Large-Enrollment Chemistry Course. Journal of Chemical Education, 90(5), 671-672. Retrieved from https://dx.doi.org/10.1021/ed3005825 $10.1021 /$ ed 3005825

Conole, G., \& Culver, J. (2010). The design of Cloudworks: Applying social networking practice to foster the exchange of learning and teaching ideas and designs. Computers \& Education, 54(3), 679-692. https://doi.org/10.1016/j.compedu.2009.09.013

Cotton, K. (1996). School size, school climate, and student performance. Northwest Regional Education Laboratory.

Daly, A. J., Moolenaar, N. M., Bolivar, J. M., \& Burke, P. (2010). Relationships in reform: the role of teachers' social networks. Journal of Educational Administration, 48(3), 359-391. https:// doi.org/10.1108/09578231011041062

de Laat, M., Lally, V., Lipponen, L., \& Simons, R.-J. (2007). Investigating patterns of interaction in networked learning and computer-supported collaborative learning: A role for Social Network Analysis. International Journal of Computer-Supported Collaborative Learning, 2(1), 87103. https://doi.org/10.1007/s11412-007-9006-4

Dewick, P., \& Miozzo, M. (2004). Networks and innovation: sustainable technologies in Scottish social housing. $R$ and D Management, 34(3), 323-333. https://doi.org/10.1111/j.1467-9310 .2004.00342.x

Erjavec, K. (2013). Aprendizaje informal a través de Facebook entre alumnos eslovenos. Comunicar, 21(41), 117-126. http://doi.org/10.3916/C41-2013-11

Esquivel, I., \& Rojas, C. A. (2014). Uso de Facebook en ámbitos educativos universitarios: Consideraciones y recomendaciones. Apertura: Revista de Innovación Educativa, 6(2), 100-115.

Evans, C. (2014). Twitter for Teaching: Can Social Media be used to Enhance the Process of Learning? British Journal of Educational Technology, 45(5), 902-915. https://doi.org/10.1111/ bjet.12099

Fernández-Díaz, E., Rodríguez-Hoyos, C., \& Haya, I. (2017). Análisis de la investigación nacional e internacional sobre redes sociales en contextos educativos. Profesorado. Revista de currículum y formación del profesorado, 21(1), 313-332. Retrieved from https://recyt.fecyt.es/index.php/ profesorado/article/view/58065

Fleiss, J. L. (1981). Statistical methods for rates and proportions. John Wiley and Sons.

Forbes, D. (2017). Professional online presence and learning networks: Educating for ethical use of social media. International Review of Research in Open and Distributed Learning, 18(7), 175-190.

Froment, F., García, A. J., \& Bohórquez, M. R. (2017). The Use of Social Networks as a Communication Tool between Teachers and Students: A Literature Review. Turkish Online Journal of Educational Technology-TOJET, 16(4), 126-144.

Gafni, R., \& Deri, M. (2012). (SNTL \#1) Costs and Benefits of Facebook for Undergraduate Students. 
Interdisciplinary Journal of Information, Knowledge, and Management, 7(1), 045-061. https:// doi.org/10.28945/1577

Gomez, S., Andersson, H., Park, J., Maw, S., Crook, A., \& Orsmond, P. (2013). A Digital Ecosystems Model of Assessment Feedback on Student Learning. Higher Education Studies, 3(2), 41-51. https://doi.org/10.5539/hes.v3n2p41

Gonzalez, H., \& Delgado, C. R. (2016). Facebook: herramienta didáctica para el aprendizaje de la geografía. DIM: Didáctica, Innovación y Multimedia, 1-11.

Greenhow, C., Gleason, B., \& Li, J. (2014). Psychological, social, and educational dynamics of adolescents' online social networking. Media Education. Studi, ricerche, buone pratiche, 5, $115-130$.

Ha, J., \& Shin, D. H. (2014). Facebook in a standard college class: an alternative conduit for promoting teacher-student interaction. American Communication Journal, 16(1), 36-52.

Hamid, S., Waycott, J., Kurnia, S., \& Chang, S. (2015). Understanding students' perceptions of the benefits of online social networking use for teaching and learning. The Internet and Higher Education, 26, 1-9. https://doi.org/10.1016/j.iheduc.2015.02.004

Hamre, B. K., \& Pianta, R. C. (2001). Early Teacher-Child Relationships and the Trajectory of Children's School Outcomes through Eighth Grade. Child Development, 72(2), 625-638. https://doi.org/10.1111/1467-8624.00301

Hatzipanagos, S., \& John, B. A. (2017). Do Institutional Social Networks Work? Fostering a Sense of Community and Enhancing Learning. Technology, Knowledge and Learning, 22(2), 151-159. https://doi.org/10.1007/s10758-017-9300-9

Heo, G. M., \& Lee, R. (2013). Blogs and social network sites as activity systems: Exploring adult informal learning process through activity theory framework. Journal of Educational Technology \& Society, 16(4), 133-145.

Hernández, E., \& Medina, F. (2015). Estrategias de aprendizaje basadas en entornos virtuales en educación secundaria. Revista científica electrónica de Educación y Comunicación en la Sociedad del Conocimiento, 15, 163-183.

Hershkovitz, A., \& Baruch, A. F. (2013). Student-teacher relationship in the Facebook era: the student perspective. International Journal of Continuing Engineering Education and Life-Long Learning, 23(1), 33-33. https://doi.org/10.1504/ijceell.2013.051765

Hershkovizt, A., \& Forkosh-Baruch, A. (2017). Teacher-student relationship and Facebookmediated communication: Student perceptions. Comunicar, 25(53), 91-101. https://doi.org/ 10.3916/c53-2017-09

Higgins, J. P., Thomas, J., Chandler, J., Cumpston, M., Li, T., Page, M. J., \& Welch, V. A. (2019). Cochrane handbook for systematic reviews of interventions. Wiley Blackwell.

Hollyhead, A., Edwards, D. J., \& Holt, G. D. (2012). The Use of Virtual Learning Environment (VLE) and Social Network Site (SNS) Hosted Forums in Higher Education. Industry and Higher Education, 26, 369-379. https://doi.org/10.5367/ihe.2012.0115

Huang, C. (2018). Social network site use and academic achievement: A meta-analysis. Computers \& Education, 119, 76-83. https://doi.org/10.1016/j.compedu.2017.12.010

Hutchens, J. S., \& Hayes, T. (2014). In your Facebook: Examining Facebook usage as misbehavior on perceived teacher credibility. Education and Information Technologies, 19, 5-20. https:// doi.org/10.1007/s10639-012-9201-4

Irwin, C., Ball, L., Desbrow, B., \& Leveritt, M. (2012). Students' perceptions of using Facebook as an interactive learning resource at university. Australasian Journal of Educational Technology, 28(7), 1221-1232. https://doi.org/10.14742/ajet.798

Jang, Y. (2015). Convenience Matters: A Qualitative Study on the Impact of Use of Social Media and Collaboration Technologies on Learning Experience and Performance in Higher Edu- 
cation. Education for Information, 31(1-2), 73-98. Retrieved from https://doi.org/10.3233/ EFI-150948

Jiang, H., Tang, M., Peng, X., \& Liu, X. (2018). Learning design and technology through social networks for high school students in China. International Journal of Technology and Design Education, 28(1), 189-206. https://doi.org/10.1007/s10798-016-9386-8

Jones, J., Gaffney-Rhys, R., \& Jones, E. (2011). Social network sites and student-lecturer communication: an academic voice. Journal of Further and Higher Education, 35(2), 201-219. https://doi.org/10.1080/0309877x.2010.548596

Jover, G., del Rosario González Martín, M., \& Fuentes, J. L. (2015). Exploración de nuevas vías de construcción mediática de la ciudadanía en la escuela: de «Antígona» a la narrativa transmedia. Teoría de la Educación. Revista Interuniversitaria, 27(1), 69-84. https://doi.org/10.14201/ teoredu20152716984

Junco, R., Elavsky, C. M., \& Heiberger, G. (2013). Putting twitter to the test: Assessing outcomes for student collaboration, engagement and success. British Journal of Educational Technology, 44(2), 273-287. https://doi.org/10.1111/j.1467-8535.2012.01284.x

Keats, D., \& Schmidt, J. P. (2007). The genesis and emergence of Education 3.0 in higher education and its potential for Africa. First Monday(3), 12-12. https://doi.org/10.5210/fm.v12i3.1625

Keng, T. C., \& Ching, Y. K. (2015). A Comparison between Quantity Surveying and Information Technology Students on Web Application in Learning Process. Malaysian Online Journal of Educational Technology, 3(1), 1-11.

Kieslinger, B., \& Ehms, K. (2010). Autoorganización del proceso de aprendizaje. Manual del uso del software social (pp. 65-77). Win Win Consultores.

Kio, S. I. (2015). Feedback theory through the lens of social networking. Issues in Educational Research, 25(2), 135-152.

Lackovic, N., Kerry, R., Lowe, R., \& Lowe, T. (2017). Being knowledge, power and profession subordinates: Students' perceptions of Twitter for learning. The Internet and Higher Education, 33, 41-48. https://doi.org/10.1016/j.iheduc.2016.12.002

Lang, A. (2012). Exploring the potential of social network sites in relation to intercultural communication. Arts and Humanities in Higher Education, 11(1), 120-139. https://doi.org/10.1177/ 1474022210394141

Lee, J., Lee, Y., \& Kim, M. H. (2015). Perceptions of Teachers and Students towards Educational Application of SNS and its Educational Effects in Middle School Class. TOJET: Turkish Online Journal of Educational Technology, 14(4), 124-134.

Leite, F. N., Hoji, E. S., \& Junior, H. A. (2018). A Blended Learning Method Applied in Data Communication and Computer Networks Subject. IEEE Latin America Transactions, 16(1), 163-171. https://doi.org/10.1109/tla.2018.8291469

Liccardi, I., Ounnas, A., Pau, R., Massey, E., Kinnunen, P., Lewthwaite, S., ... Sarkar, C. (2007). The role of social networks in students' learning experiences. ACM SIGCSE Bulletin, 39(4), 224-237. https://doi.org/10.1145/1345375.1345442

Ling, M. M. (2014). Social Media and Social Networking Applications for Teaching and Learning. European Journal of Science and Mathematics Education, 2(1), 53-62. https://doi.org/ 10.11114/jets.v6i11a.3817

Liu, H., Maes, P., \& Davenport, G. (2006). Unraveling the Taste Fabric of Social Networks. International Journal on Semantic Web and Information Systems, 2(1), 42-71. https://doi.org/10.4018/ jswis. 2006010102

López, M. C., Flores, K., \& Espinoza, A. (2015). Diversidad de usos de Facebook en la educación superior. Análisis desde un caso de estudio. Innoeduca. International Journal of Technology and Educational Innovation, 1(2), 106-106. https://doi.org/10.20548/innoeduca.2015.v1i2.1040 
López-Bonilla, J. M., \& López-Bonilla, L. M. (2013). Exploring the relationship between social networks and collaborative learning. British Journal of Educational Technology, 44(5), E139E142. https://doi.org/10.1111/bjet.12003

Madge, C., Meek, J., Wellens, J., \& Hooley, T. (2009). Facebook, social integration and informal learning at university: 'It is more for socialising and talking to friends about work than for actually doing work. Learning, Media and Technology, 34(2), 141-155. https://doi.org/10 $.1080 / 17439880902923606$

Manca, S., \& Ranieri, M. (2017). Implications of social network sites for teaching and learning. Where we are and where we want to go. Education and Information Technologies, 22(2), 605622. https://doi.org/10.1007/s10639-015-9429-x

Maroulis, S., \& Gomez, L. M. (2008). Does "connectedness" matter? Evidence from a social network analysis within a small-school reform. Teachers College Record, 110(9), 1901-1929.

Martínez, A., Dimitriadis, Y., Rubia, B., Gómez, E., \& de la Fuente, P. (2003). Combining qualitative evaluation and social network analysis for the study of classroom social interactions. Computers \& Education, 41(4), 353-368. https://doi.org/10.1016/j.compedu.2003.06.001

Martínez, M. (2014). Redes sociales y TIC, su papel en la educación superior del siglo XXI. Historia y comunicación social, 19, 63-71. http://doi.org/10.5209/rev_HICS.2014.v19.45108

Martínez, M., Esteban, F., Jover, G., \& Payá, M. (2018). De la autoridad al liderazgo. La educación, en teoría (pp. 35-37). Síntesis.

Mazer, J. P., Murphy, R. E., \& Simonds, C. J. (2007). I'll See You On "Facebook": The Effects of Computer-Mediated Teacher Self-Disclosure on Student Motivation, Affective Learning, and Classroom Climate. Communication Education, 56(1), 1-17. https://doi.org/10.1080/ 03634520601009710

Mccarthy, J. (2010). Blended learning environments: Using social networking sites to enhance the first year experience. Australasian Journal of Educational Technology, 26(6), 729-740. https:// doi.org/10.14742/ajet.1039

Molinillo, S., Anaya-Sánchez, R., Aguilar-Illescas, R., \& Vallespín-Arán, M. (2018). Social mediabased collaborative learning: Exploring antecedents of attitude. The Internet and Higher Education, 38(1), 18-27. https://doi.org/10.1016/j.iheduc.2018.04.003

Morón, J. A., López, F., \& Cobos, D. (2017). El uso de las redes sociales en educación para la salud: Una experiencia de empoderamiento social en Nicaragua. Profesorado. Revista de Currículum y Formación del Profesorado, 21(4), 439-457. Retrieved from http://hdl.handle.net/10481/ 49040

Nagel, T. W., Remillard, C., Aucoin, R., \& Takenishi, A. (2018). Findings on Student Use of Social Media at the Collegiate, Undergraduate, and Graduate Levels: Implications for PostSecondary Educators. Journal of University Teaching \& Learning Practice, 15(1). Retrieved from http://ro.uow.edu.au/jutlp/vol15/iss1/8

Nagle, J. (2018). Twitter, cyber-violence, and the need for a critical social media literacy in teacher education: A review of the literature. Teaching and Teacher Education, 76, 86-94. https:// doi.org/10.1016/j.tate.2018.08.014

Norman, H., Nordin, N., Din, R., Ally, M., \& Dogan, H. (2015). Exploring the Roles of Social Participation in Mobile Social Media Learning: A Social Network Analysis. The International Review of Research in Open and Distributed Learning, 16(4). https://doi.org/10.19173/irrodl .v16i4.2124

Ormart, D. E., \& Navés, P. F. A. (2014). El uso de redes sociales como soporte educativo. CPU-e, Revista de Investigación Educativa, 18(18), 162-171. https://doi.org/10.25009/cpue.v0i18.760

Padilla, G. (2012). Modalidades de uso y razones de éxito de las redes sociales entre los jóvenes universitarios españoles para su aplicación al Espacio Europeo de Educación Superior (EEES). 
Estudios sobre el Mensaje Periodístico, 18, 671-679. https://doi.org/10.5209/rev_ESMP.2012 .v18.40946

Palacios, M. M.-A. (2012). El proceso de enseñanza a través de sitios de redes sociales: hacia un nuevo modelo o estilo de enseñanza. Estudios sobre el Mensaje Periodístico, 18, 617-628. https://doi.org/10.5209/rev_esmp.2012.v18.40941

Paul, J. A., Baker, H. M., \& Cochran, J. D. (2012). Effect of online social networking on student academic performance. Computers in Human Behavior, 28(6), 2117-2127. https://doi.org/ 10.1016/j.chb.2012.06.016

Pérez, A., Tur, G., Negre, F., \& Lizana, A. (2017). Factores de éxito de las comunidades virtuales universitarias basadas en redes sociales. Análisis de XarFED. Revista Complutense de Educación, 28(2), 497-515. https://doi.org/10.5209/rev_rced.2017.v28.n2.49568

Phungsuk, R., Viriyavejakul, C., \& Ratanaolarn, T. (2017). Development of a problem-based learning model via a virtual learning environment. Kasetsart Journal of Social Sciences, 38(3), 297-306. https://doi.org/10.1007/s40692-014-0015-9

Putnik, G., Costa, E., Alves, C., Castro, H., Varela, L., \& Shah, V. (2016). Analysing the correlation between social network analysis measures and performance of students in social networkbased engineering education. International Journal of Technology and Design Education, 26(3), 413-437. https://doi.org/10.1007/s10798-015-9318-Z

Rama, M., \& Chiecher, A. (2012). Hacia una nueva docencia. Perspectivas de estudiantes universitarios acerca de la participación del docente en las redes sociales. Revista de Educación a Distancia, 6, 1-16. Retrieved from https://revistas.um.es/red/article/view/245191

Raywid, M. A. (1997). Small schools: A reform that works. Educational Leadership, 55(4), 34-39.

Renes-Arellano, P., Caldeiro-Pedreira, M. C., del Mar Rodríguez-Rosell, M., \& Aguaded, I. (2018). Educlips: proyecto de alfabetización mediática en el ámbito universitario. Lumina, 12(1), 17-39. https://doi.org/10.34019/1981-4070.2018.v12.21485

Rezende, F., van Kruistum, C., \& van Oers, B. (2016). Teachers and Facebook: using online groups to improve students' communication and engagement in education. Communication Teacher, 30, 228-241. https://doi.org/10.1080/17404622.2016.1219039

Ricoy, M. C., \& Feliz, T. (2016). Twitter as a learning community in higher education. Journal of Educational Technology \& Society, 19(1), 237-248.

Rienties, B., \& Kinchin, I. (2014). Understanding (in)formal learning in an academic development programme: A social network perspective. Teaching and Teacher Education, 39, 123-135. https://doi.org/10.1016/j.tate.2014.01.004

Roblyer, M. D., McDaniel, M., Webb, M., Herman, J., \& Witty, J. V. (2010). Findings on Facebook in higher education: A comparison of college faculty and student uses and perceptions of social networking sites. The Internet and Higher Education, 13, 134-140. https://doi.org/10.1016/ j.iheduc.2010.03.002

Rodríguez, J. S., Ruiz-Palmero, J., \& Rivas, E. S. (2015). Uso problemático de las redes sociales en estudiantes universitarios. Revista Complutense de Educación, 26(0), 159-174. https://doi.org/ 10.5209/rev_rced.2015.v26.46360

Rodríguez-Hoyos, C., Salmón, I. H., \& Fernández-Díaz, E. (2015). Research on SNS and education: The state of the art and its challenges. Australasian Journal of Educational Technology, 31(1), 100-111. https://doi.org/10.14742/ajet.995

Romero, C., López, M.-I., Luna, J.-M., \& Ventura, S. (2013). Predicting students’ final performance from participation in on-line discussion forums. Computers \& Education, 68, 458-472. https:// doi.org/10.1016/j.compedu.2013.06.009

Russo, T. C., \& Koesten, J. (2005). Prestige, Centrality, and Learning: A Social Network Analysis of an Online Class. Communication Education, 54(3), 254-261. https://doi.org/10.1080/ 


\section{4}

Sabol, T. J., \& Pianta, R. C. (2012). Recent trends in research on teacher-child relationships. Attachment \& Human Development, 14(3), 213-231. https://doi.org/10.1080/14616734.2012 .672262

Sadowski, C., Pediaditis, M., \& Townsend, R. (2016). University students' perceptions of social networking sites (SNSs) in their educational experiences at a regional Australian university. Australasian Journal of Educational Technology, 33(5). https://doi.org/10.14742/ajet.2927

Saifudin, A. M., Yacob, A., \& Saad, R. (2016). The Facebook-in-action: Challenging, Harnessing and Enhancing Students Class Assignments and Projects. Universal Journal of Educational Research, 4(6), 1259-1265. https://doi.org/10.13189/ujer.2016.040602

Seifert, T. (2016). Involvement, collaboration and engagement: Social networks through a pedagogical lens. Journal of Learning Design, 9(2), 31-45. https://doi.org/10.5204/jld.v9i2.272

Selwyn, N. (2009). Faceworking: Exploring students' education-related use of Facebook. Learning, Media and Technology, 34(2), 157-74. https://doi.org/10.1080/17439880902923622

Sobaih, A. E. E., Moustafa, M. A., Ghandforoush, P., \& Khan, M. (2016). To use or not to use? Social media in higher education in developing countries. Computers in Human Behavior, 58, 296-305. https://doi.org/10.1016/j.chb.2016.01.002

Thalluri, J., \& Penman, J. (2015). Social Media for Learning and Teaching Undergraduate Sciences: Good Practice Guidelines from Intervention. Electronic Journal of e-Learning, 13(6), 455-465. Retrieved from https://files.eric.ed.gov/fulltext/EJ1087212.pdf

Túñez, M., \& Sixto, J. (2012). Las redes sociales como entorno docente: análisis del uso de Facebook en la docencia universitaria. Pixel-Bit. Revista de Medios y Educación, 41, 77-92. Retrieved from https://idus.us.es/xmlui/handle/11441/22656

Valero, A., Vendrell, M., \& Camas, L. (2018). Análisis de la literatura académica actual sobre las redes sociales y su potencial educativo. VIII Congreso Iberoamericano de Pedagogía. CIP 2018, august 14-17th, Buenos Aires (pp. 14-17).

Valero, A., Vendrell, M., \& Camas, L. (2020). The educational use of Social Networks Sites: a comparative analysis between the Spanish and English production. Digital Education Review, 37, 304-322. https://doi.org/10.1344/der.2020.37.304-322

Vázquez-Martínez, A. I., \& Cabero-Almenara, J. (2015). Las redes sociales aplicadas a la formación. Revista complutense de educación, 26, 253-272. http://doi.org/10.5209/rev_RCED.2015.v26 .47078

Vercellone-Smith, P., Jablokow, K., \& Friedel, C. (2012). Characterizing communication networks in a web-based classroom: Cognitive styles and linguistic behavior of self-organizing groups in online discussions. Computers \& Education, 59(2), 222-235. https://doi.org/10.1016/ j.compedu.2012.01.006

Wang, J. (2013). What Higher Educational Professionals Need to Know about Todaýs Students. Online Social Networks. TOJET: Turkish Online Journal of Educational Technology, 12(3), 180193.

Wang, R. B., \& Du, C. T. (2014). Mobile Social Network Sites as innovative pedagogical tools: factors and mechanism affecting students' continuance intention on use. Journal of Computers in Education, 1(4), 353-370. https://doi.org/10.1007/s40692-014-0015-9

Wnuk, K., \& Garrepalli, T. (2018). Knowledge management in software testing: a systematic snowball literature review. Informatica Software Engineering Journal, 12(1), 51-78.

Wodzicki, K., Schwämmlein, E., \& Moskaliuk, J. (2012). “Actually, I Wanted to Learn”: Studyrelated knowledge exchange on social networking sites. The Internet and Higher Education, 15(1), 9-14. https://doi.org/10.1016/j.iheduc.2011.05.008

Wohlin, C. (2014). Guidelines for snowballing in systematic literature studies and a replication 
in software engineering. Proceedings of the 18th international conference on evaluation and assessment in software engineering, 38, 1-10. https://doi.org/10.1145/2601248.2601268

$\mathrm{Wu}, \mathrm{T}$. (2014). Using smart mobile devices in social-network-based health education practice: A learning behavior analysis. Nurse Education Today, 34(6), 958-963. https://doi.org/10.1016/ j.nedt.2014.01.013

Yakın, I., \& Tinmaz, H. (2015). Theoretical guidelines for the utilization of instructional social networking websites. Turkish Online Journal of Distance Education-TOJDE, 16(4), 67-83. 